\title{
Four new cases of ring 21 and 22 including familial transmission of ring 21
}

\author{
C. G. PALMER, M. E. HODES, T. REED, and J. KOJETIN* \\ From the Department of Medical Genetics, Indiana University School of Medicine, Indianapolis, Indiana, USA
}

SUMMARY Four new cases of ring $\mathrm{G}$ chromosomes are presented including one family in which the ring 21 is present in a mother and in her daughter, who has $47, \mathrm{XXX}, \mathrm{r}(21)$ chromosomes. The clinical and dermatoglyphic findings in $\mathrm{r} 21$ and $\mathrm{r} 22$ syndromes are reviewed.

G-deletion syndromes are associated with various cytogenetic findings. These include complete monosomy, monosomy-mosaicism, partial deletion of the long arm of a $\mathrm{G}$ group chromosome or mosaicism for such a deletion, translocation, or ring $G$ chromosomes.

While some of the translocations resulting in unbalanced segments with G-deletion syndrome have been familial the only evidence suggesting transmission of a ring $G$ from parent to child occurred in a family with chromosome instability and mosaicism (Zdansky et al, 1969). In this paper we present the unusual finding of familial $\mathrm{r} 21$ in a mother and child. The daughter also carries an extra $X$. Two other cases of ring $G$ are presented, one $r 21$ and the other $\mathrm{r} 22$. These 4 individuals with ring $\mathrm{G}$ identified in banded chromosomes have given us the opportunity to review the literature of $\mathrm{G}$ deletion syndromes in which the chromosomes have been clearly identified by one of the several banding procedures. We have not included those cases resulting from translocations since such individuals may also carry an excess of genetic material derived from the translocation partner.

Since there are diverse cytogenetic findings in the G-deletion syndromes it is not unexpected that the clinical picture also varies. Warren and Rimoin (1970) described two separate clinical entities, the G1 and G2 deletion syndromes and related them to deletion of chromosomes 21 and 22 , respectively (Warren et al, 1973). Our work confirms the existence of two syndromes while pointing out the

Received for publication 16 February 1976

* This is publication No. 75-24 from the Department of Medical Genetics and was supported in part by the Indiana University Human Genetics Center (PHS P01 GM 21054) and the James Whitcomb Riley Memorial Association. hazards of making the diagnosis on phenotype alone or even when nonbanded chromosomes indicate a G-deletion.

\section{Case reports}

\section{Case 1 Family 21209}

This proband was a 6-day-old white girl, born to 27-year-old parents. The birthweight was $3090 \mathrm{~g}$, occipital-frontal circumference (OFC) $38 \mathrm{~cm}$ (>97th centile), length $51 \mathrm{~cm}$ (75th centile). Clinical findings included: preauricular pits, hypoplastic mandible, simple vermillion border with long, flat philtrum, wide open metopic suture, high scalp hair, intact but high, narrow palate, grade $1-2 / 6$ systolic ejection murmur along the left sternal border, palpable pole of the left kidney, thumbs held under the fingers and upper extremities flexed, hyperextensible joints, stiff legs, bilaterally dislocated hips, hypolastic toenails, marked hypotonia, and wide spaced nipples. There was microphthalmus of the right eye and smooth cysts on the lower lids. The murmur was thought to be consistent with persistent ductus arteriosus. $X$-ray examination showed a small mandible, the superior mediastinum widened secondary to an enlarged thymus gland, ribs and bones of the hands and feet thin and fragile, and lateral malpositioning of both femoral heads in relation to the acetabulum with normal acetabular angles bilaterally. The kidneys were somewhat large on intravenous pyelogram.

The electrocardiogram was normal. Laboratory values included: normal serum calcium, creatinine, and chloride, and raised $(7.3 \mathrm{mmol} / \mathrm{l})$ potassium and low $(16 \mathrm{mmol} / \mathrm{l})$ bicarbonate. The urine contained some epithelial cells and bacteria. Haemoglobin, haematocrit, platelets, and erythrocytes were normal. There was 13800 leucocytes $/ \mathrm{mm}^{3}, 2 \%$ bands, $41 \%$ polymorphonuclear leucocytes, $51 \%$ lymphocytes, and $6 \%$ monocytes. During her stay in the hospital the patient was lethargic and a poor feeder. She was gavaged at times and there was occasional vomiting. 


\section{Case 2 Family 22047}

This proband was a 20-day-old white girl who was born to 21-year-old parents. The patient was admitted to the hospital with cyanosis aggravated by crying. Physical findings included OFC $32 \mathrm{~cm}$ (2nd centile), length $48 \mathrm{~cm}$ ( $3 \mathrm{rd}$. centile), anterior fontanelle $1.5 \mathrm{~cm}$, dark silky hair extending over the forehead to the upper lids, a lower milk tooth, systolic murmur heard over the praecordium and loudest at the left sternal border, poorly developed clitoris and labia, long thin toes, and tapering and scissoring of the legs.

The electrocardiogram showed right axis deviation and right ventricular hypertrophy. On $x$-ray examination the heart was at the upper limit of normal. Electroencephalogram was diffusely slow for her age with a high amplitude delta rhythm, but there were no evidences of lateralization or spikes. Neurological examination showed only minimal spasticity. The laboratory examinations included: normal serum calcium and electrolytes, BUN $19 \mathrm{mg} / 100 \mathrm{ml}$. The urine was loaded with epithelial cells and a few bacteria. The haemoglobin concentration was $16.7 \mathrm{~g} / \mathrm{dl}$, leucocyte count $17400 / \mathrm{mm}^{3}$, reticulocytes $0.2 \%$. Culture of the eye showed Staphylococcus epidermidis, $H$. influenzae, and diphtheroids. An $x$-ray film of the skull was normal and a chest $x$-ray examination showed an enlarged heart and findings suggestive of transposition of the great vessels.

The baby did poorly in the hospital and was discharged at the family's request. She died at age 72 days. No necropsy was performed.

\section{Case 3 Family 1223}

This child was a white girl, and was 5 years old when first examined (1972). She was born to a 30-year-old mother. Her birthweight was $2637 \mathrm{~g}$. She did not walk until 18 months and was said to be 'clumsy'. Little else was known of her earlier years except that she had been in 17 foster homes. At age 8, she was hyperactive, overly affectionate, $130.5 \mathrm{~cm}$ (75th centile) tall, and weighed $23.8 \mathrm{~kg}(25-50$ th centile). She had a peculiar posture, with hip partially bent and stomach protruding, a mildly uncoordinated gait, and a normal range of motion of all joints. Her hips were internally rotated, but were said to be within normal limits for age and activity. The OFC $(50.4 \mathrm{~cm})$ was normal. There were prominent epicanthal folds, a wide, flat nasal bridge, sparse eyebrows (particularly laterally), little hair over the extremities, some coarse, brown labial hair, but no axillary hair or breast development. There was minimal fleshy syndactyly at the base of the third and fourth fingers and of the left second and third toes and right third and fourth toes. There was distinct mental retardation and retarded bone age. The patient and her mother are shown in Fig. 1.

The electrocardiogram was normal. The electroencephalogram was abnormal with bisynchronous, irregular $2.5-3 \mathrm{c} / \mathrm{s}$ spike and wave activity during wake and sleep recordings. The findings were suggestive of a bilateral diffuse cerebral hemispheric disturbance, and suggested that the patient was susceptible to seizures of

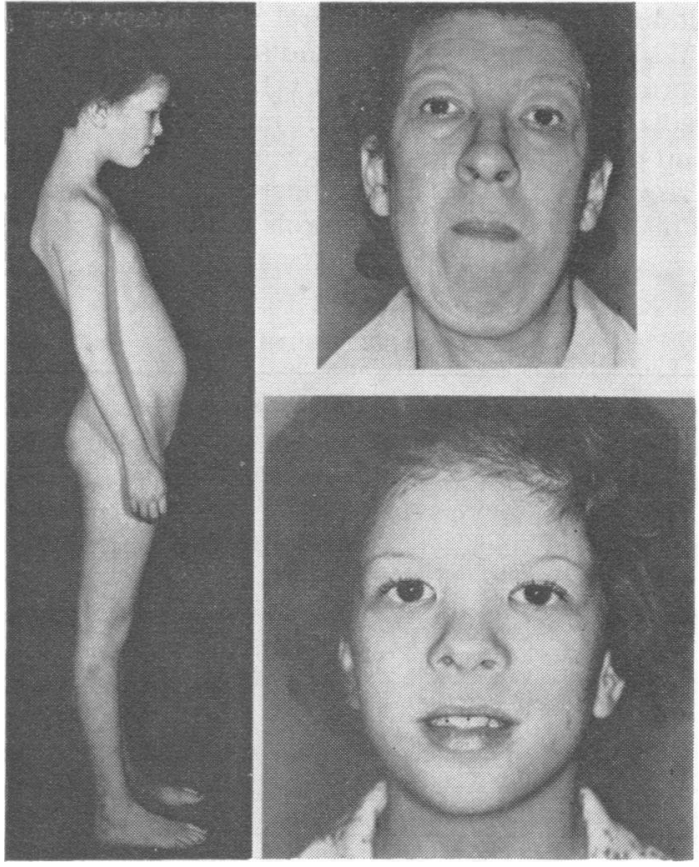

FIG. 1. Case 3 and her mother Case 4.

the primary generalized type. $X$-ray films showed thoracic spine fusion of T4-5 on the left.

\section{Case 4 Family 1223}

A white 38-year-old female. She is the mother of Case 3. She has three children, each by a different father. Only Case 3 is said to be abnormal. The other two children were given for adoption. Clinical findings of the mother included: mild mental retardation, distinct kyphosis, and prominent abdomen, minimal diastasis recti, long face with small chin button, and parallel rami of the mandibles which lent a squared-off appearance to the jaw, sparse eyebrows, and sparse hair on the extremities. The upper lids and area below the eyes were puffy. There were a depressed nasal bridge, prominent alveolar ridging, nails somewhat smaller than normal and slightly spooned, and long second toes.

\section{Cytogenetic findings}

The cytogenetic findings in the 4 cases are summarized in Table I and Figs. 2, 3, and 4. The ring chromosomes of Cases 3 and her mother, Case 4, were similar in size. The mother's parents both had normal chromosomes.

\section{Dermatoglyphic findings}

The dermatoglyphic findings of the four patients are listed in Table II. There are several unusual 
findings. Case 2 has bilateral radial loops on the middle fingers. This is found in fewer than $1 \%$ of normal controls ( $\mathrm{Lu}, 1968)$. In our laboratory a radial loop occurs on the left middle finger in 3\% and on the right middle finger in $1.5 \%$ of controls. Case 1 had 8/10 whorls and bilateral $t^{\prime \prime}$ axial triradii. This is found in $4 \%$ of controls in our series $\left(t^{\prime \prime}\right.$ on

TABLE I

CYTOGENETIC FINDINGS

\begin{tabular}{|c|c|c|c|c|}
\hline & & \multicolumn{2}{|c|}{$\begin{array}{l}\text { No. of Cells } \\
\text { Examined }\end{array}$} & \multirow[b]{2}{*}{ Double Rings } \\
\hline \multirow{2}{*}{ Case 1} & \multirow[b]{2}{*}{$\begin{array}{l}46, \mathrm{XX}, \mathrm{r}(22) \\
\text { Leucocytes } \\
\text { Fibroblasts }\end{array}$} & Diploid & $-r$ & \\
\hline & & $\begin{array}{r}75 \\
200\end{array}$ & $\begin{array}{r}0 \\
10\end{array}$ & $\begin{array}{l}1 \\
0\end{array}$ \\
\hline Case 2 & $\begin{array}{l}\text { 46,XX,r(21) } \\
\text { Bone marrow } \\
\text { Leucocytes }\end{array}$ & $\begin{array}{r}6 \\
50\end{array}$ & $\begin{array}{l}\mathbf{0} \\
\mathbf{0}\end{array}$ & $\begin{array}{l}1 \\
0\end{array}$ \\
\hline Case 3 & $\begin{array}{l}\text { 47,XXX,r(21) } \\
(1972) \text { Leucocytes } \\
\text { (1973) Leucocytes } \\
\text { (1975) Leucocytes }\end{array}$ & $\begin{array}{r}59 \\
14 \\
100\end{array}$ & $\begin{array}{l}\mathbf{0} \\
\mathbf{0} \\
\mathbf{0}\end{array}$ & $\begin{array}{l}1 \\
1 \\
0\end{array}$ \\
\hline & & $\overline{173}$ & & \\
\hline Case 4 & $\begin{array}{l}\text { 46,XX,r(21) } \\
\text { Leucocytes }\end{array}$ & 98 & 2 & \\
\hline
\end{tabular}

the left occurs in approximately $7 \%$ and on the right in $9 \%$ ). In addition large patterns in the hypothenar areas were associated with the distal axial triradii (ulnar loop-left, whorl-right). The frequency of these patterns in our controls are $6 \%$ and $2 \%$, respectively. Case 3 had a tented arch (3\% of controls) on the left hallucal area and there was an absence of the digital triradius on the left palm ( $<1 \%$ of controls). Her mother (Case 4$)$ had an absent $\mathrm{d}$ on the left palm. In addition there was an absent axial triradius on the right palm of Case 4 associated with a hypothenar radial arch pattern ( $2 \%$ and $3 \%$ of controls, respectively), and 9 of 10 digits had whorl or whorl subtypes.

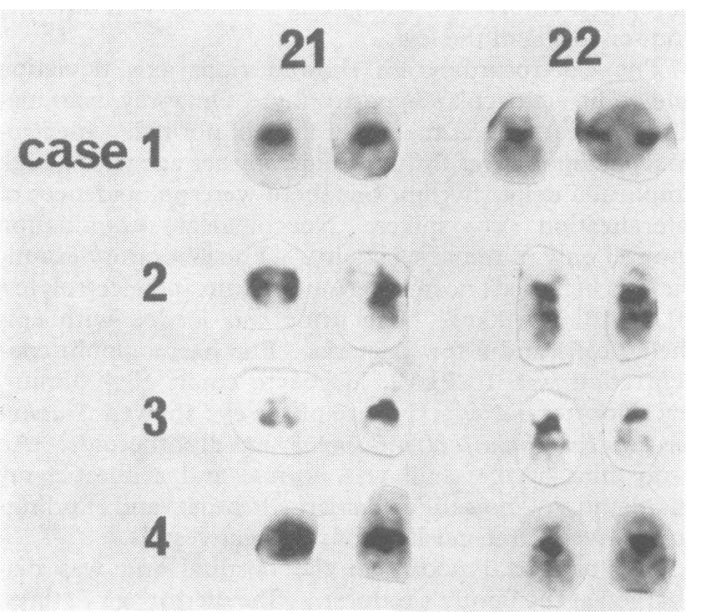

FIG. 2. Partial karyotype showing ring 22 (double sized ring) of Case 1 and ring 21 of Cases 2, 3, and 4 (Trypsin banding).

\section{Discussion}

We present here 4 new cases of ring $G$ chromosomes. Ring chromosomes are formed by simul-

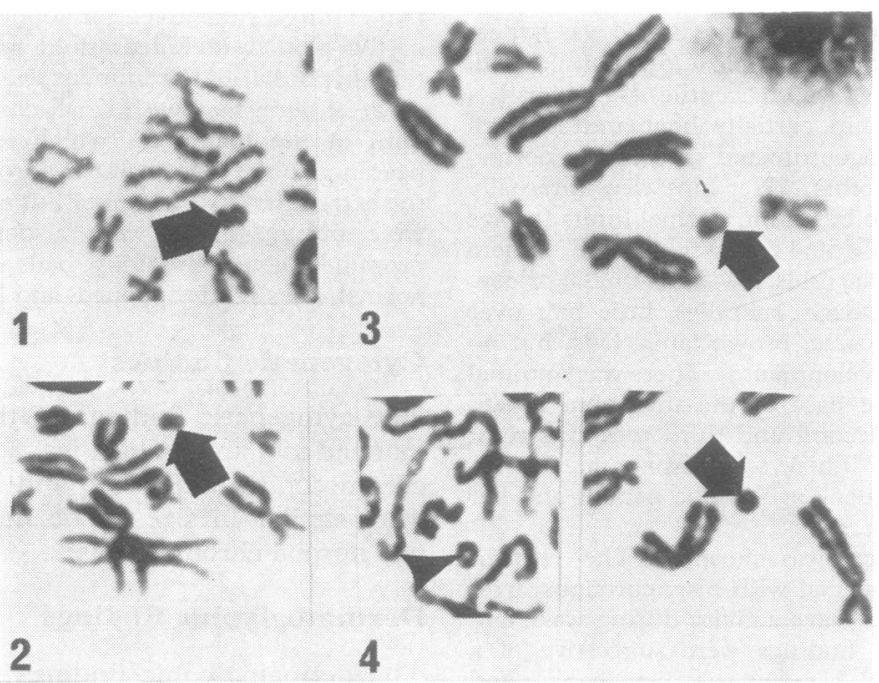

FIG. 3. Unbanded ring chromosomes of Cases 1, 2, 3, and 4, respectively. 


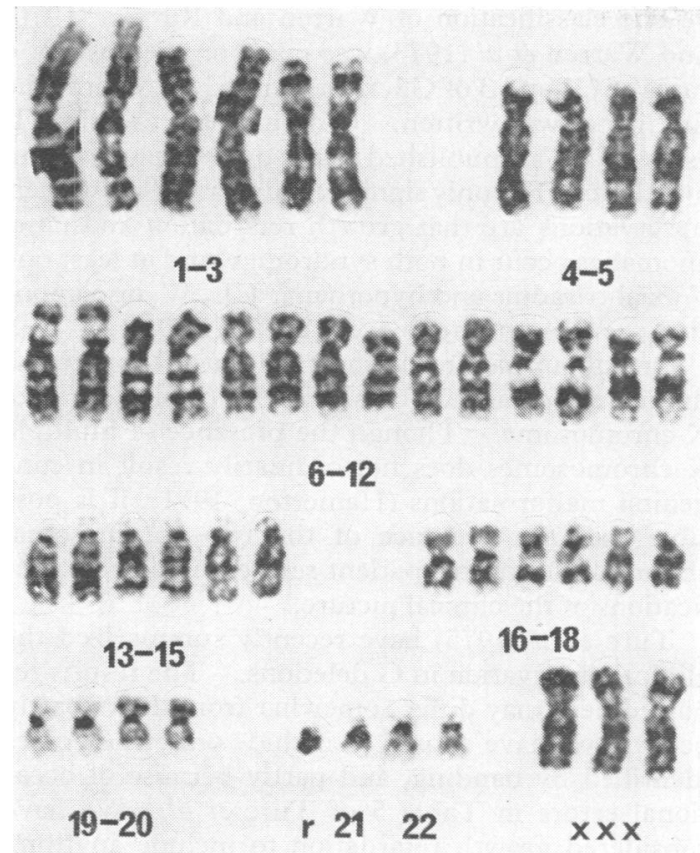

FIG. 4. Karyotype of Case 3 showing karyotype 47,XXX,r(21).

TABLE II

DERMATOGLYPHIC FINDINGS IN FOUR CASES OF RING G

I Fingers

\begin{tabular}{|c|c|c|c|c|c|c|c|c|c|c|}
\hline Case & $\underset{\text { I }}{\text { Left }}$ & II & III & IV & V & $\underset{\text { I }}{\text { Right }}$ & II & III & IV & V \\
\hline $\begin{array}{l}1 \\
2 \\
3 \\
4\end{array}$ & $\begin{array}{l}\mathbf{W} \\
\mathbf{A} \\
\mathbf{L}^{\mathbf{u}} \\
\mathbf{W}^{* *}\end{array}$ & $\begin{array}{l}\mathbf{L}^{\mathrm{r}} \\
\mathbf{A} \\
\mathbf{W} \\
\mathbf{W}\end{array}$ & $\begin{array}{l}W^{W} \\
L^{r} \\
W^{* *} \\
W^{* *}\end{array}$ & $\begin{array}{l}\mathbf{W} \\
\mathbf{L}^{\mathbf{u}} \\
\mathbf{L}^{\mathbf{u}} \\
\mathbf{W}\end{array}$ & $\begin{array}{l}\mathrm{W} \\
\mathrm{W} \\
\mathrm{L}^{\mathrm{u}} \\
\mathrm{W}^{*}\end{array}$ & $\begin{array}{l}\mathbf{L}^{\mathbf{u}} \\
\mathbf{A}^{\mathrm{u}} \\
\mathbf{L}^{\mathrm{u}} \\
\mathbf{L}^{\mathrm{u}}\end{array}$ & $\begin{array}{l}\mathbf{W} \\
\mathbf{L}^{u} \\
\mathbf{L}^{r} \\
\mathbf{W}\end{array}$ & $\begin{array}{l}\mathbf{W} \\
\mathbf{L}^{r} \\
\mathbf{W} \\
\mathbf{W}\end{array}$ & $\begin{array}{l}\mathbf{W} \\
\mathbf{L}^{\mathbf{u}} \\
\mathbf{W} \\
\mathbf{W}\end{array}$ & $\begin{array}{l}\mathbf{W}^{*} \\
\mathbf{L}^{u} \\
\mathrm{~L}^{\mathrm{u}} \\
\mathbf{W}^{*}\end{array}$ \\
\hline
\end{tabular}

*Central pocket $\quad * *$ Twin or double loop

II Palm

\begin{tabular}{|c|c|c|}
\hline Case & Left & Right \\
\hline $\begin{array}{l}1 \\
2 \\
3 \\
4\end{array}$ & $\begin{array}{l}\mathrm{t}^{\prime \prime}\left(48^{\circ}\right) \cdot L^{\mathrm{u}} \cdot O \cdot O \cdot \mathrm{L}^{\mathrm{d}} \cdot 0 \\
\mathrm{t}(-)_{0} \mathrm{O} \cdot \mathrm{O} \cdot \mathrm{O} \cdot \mathrm{O} \cdot \mathrm{L}^{\mathrm{d}} \\
\mathrm{t}^{\prime}\left(31^{\circ}\right) \cdot O \cdot O \cdot O \cdot O \cdot O \\
\mathrm{t}^{\prime}\left(32^{\circ}\right) \cdot \mathrm{L}^{\mathrm{r}} \cdot O \cdot O \cdot O \cdot O\end{array}$ & $\begin{array}{l}\mathrm{t}^{\prime \prime}\left(56^{\circ}\right) \cdot W \cdot O \cdot L^{d} \cdot L^{d} \cdot O \\
t^{\prime}\left(26^{\circ}\right) \cdot O \cdot O \cdot O \cdot O \cdot L^{d} \\
t^{\prime}\left(33^{\circ}\right) \cdot L^{r} \cdot O \cdot O \cdot O \cdot L^{d} \\
\text { absent t. Ar.O.O.O. } L^{d}\end{array}$ \\
\hline
\end{tabular}

All normal creases, Cases 3, 4 absent $d$ left

III Sole

\begin{tabular}{|c|c|c|c|c|}
\hline Case & Left & Big Toe & Right & Big Toe \\
\hline $\begin{array}{l}1 \\
2 \\
3 \\
4\end{array}$ & 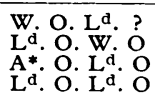 & $\begin{array}{l}\text { W } \\
\text { A } \\
\text { A } \\
\text { A }\end{array}$ & $\begin{array}{l}\mathrm{W} \cdot O \cdot \mathrm{L}^{\mathrm{d}} \cdot \mathrm{O} \\
\mathrm{L}^{\mathrm{d}} \cdot O \cdot \mathrm{L}^{\mathrm{d}} \cdot \mathrm{O} \\
\mathrm{L}^{\mathrm{d}} \cdot \mathrm{L}_{\mathrm{p}} \cdot \mathrm{Ld}^{\mathrm{d}} \cdot \mathrm{O} \\
\mathrm{W} \cdot O \cdot \mathrm{L}^{\mathrm{d}} \cdot \mathrm{O}\end{array}$ & $\begin{array}{l}\mathrm{W} \\
? \\
\mathrm{~A} \\
\mathrm{~A}\end{array}$ \\
\hline
\end{tabular}

* Tented arch taneous breakage and reunion at both ends of a chromosome. Somatic crossing over within the ring may produce dicentric and interlocking rings. These rings encounter difficulties in distribution and may undergo breakage and reunion at anaphase. This leads to rings of unequal size. Alternatively, the interlocked ring may mis-segregate with the ring being lost from the cell or appearing as a double sized ring in one cell. In corn, instability of rings has been related to size (McClintock, 1938), the larger rings being more unstable than the smaller ones. More recent studies in both man (Kinstenmacher and Punnett, 1970) and corn (Schwartz, 1958) suggest that the genetic content of a ring chromosome may determine its stability. Kistenmacher and Punnett studied two human ring chromosomes, one of the $C$ and one of the $D$ group and found dicentric and interlocked rings in $\mathrm{D}$ rings, but not in the larger C9. They concluded that the genetic content of the ring influences stability of the ring in man. Nakagome et al (1973) have also described a large ring (of chromosome 5) characterized by its stability.

In our patients, and in the published reports (Lindenbaum et al, 1973; Cases 1 and 2 in this paper), double-sized rings have been rare. By contrast, $\mathrm{G}$ rings appear to be lost with some regularity. Mosaics with 45 chromosomes and lacking the $G$ ring are common. Some patients seem to carry a ring in every cell, but even here firm conclusions are not possible since often only one tissue (the leucocyte) has been studied. Indeed, evidence from other mosaics suggests that selection is continually active in the rapidly dividing haematopoietic tissue and may lead to survival of only one population, while divisions from skin or other tissue cultures are more likely to demonstrate the two cell populations of a mosaic. In our patients, mosaicism appears to be at a low level in haematopoietic tissue. The fibroblast cultures obtained from one patient showed more frequent loss of the ring.

Since ring chromosomes are formed by breaks in both long and short arms, it is possible to get deletions of varying length. Deletions of the short arms of $\mathrm{G}$ chromosomes do not appear to be associated with any known clinical abnormality (Neu et al, 1966; Migeon, 1965). Loss of differing lengths of the long arm may occur during formation of ring chromosomes. Crossovers resulting in double sized rings produce duplication of genetic information. Such differences in length of $\mathrm{Gq}$, as well as differing amounts of mosaicism resulting from abnormalities in distribution of the ring, contribute to the great variability seen in the clinical findings of these patients and make it less likely that those 
patients identified as $\mathrm{r} 21$ or $\mathrm{r} 22$ by banding methods will be phenotypically identical.

Our consideration of the clinical findings of $G$ deletions has been limited to reported cases in which the chromosomes were banded. The karyotypes were divided into three groups; ring 21 chromosomes, chromosome 21 deletions and monosomies, and 22 deletions (Table III). From the data presented, it may be noted that there are features common to all three conditions and others relatively specific for the chromosome 21 or chromosome 22 abnormalities. There were no clinical features that could be used to distinguish the $46,21 \mathrm{r}$ from the $46,21 \mathrm{q}$ - or $45,-21$ patients, though presence of a hernia or genitourinary tract anomalies might make the former more probable. The regularly recurring features distinguishing 21 and 22 deletions were epicanthal folds, hypotonia, and syndactyly of the second and third toes in the latter, and micrognathia, cardiovascular anomalies, hernia or genitourinary anomalies, antimongoloid slant, and hypertonia in the 21 anomalies. Epicanthal folds occur so regularly in the $22 \mathrm{r}$ and micrognathia in the $21 \mathrm{r}$ defects that one ought not to make a clinical diagnosis in their absence. It should also be noted that there is a preponderance of females in all $\mathrm{G}$ deletions.
The classification of Warren and Rimoin (1970) and Warren et al (1973) was made on the basis of 6 cases of G1 and 3 of G2, none banded at the time the first paper was written. Our summary (Table III) is based on all published banded cases plus 4 from our clinic. The only significant deviations from their observations are that growth retardation and nasal anomalies occur in both syndromes, and at least one $t^{\prime \prime}$ axial triradius and hypothenar UL, W, or composites are more prone to occur in G2 (r22).

One of our patients with $\mathrm{r} 21$ did have the unusual finding of epicanthal folds, but also carried an extra $\mathrm{X}$ chromosome. Though the presence of multiple $\mathrm{X}$ chromosomes does not ordinarily result in congenital malformations (Hamerton, 1971), it is possible that the presence of the two chromosomal abnormalities in this patient resulted in some modifications of the clinical picture.

Turc et al (1975) have recently summarized the clinical observation in $\mathrm{G}$ deletions. The results reported here may differ somewhat from theirs partly because we have chosen to include only those cases identified by banding, and partly because of occasional errors in Table 5 of Turc et al. We have considered growth retardation to include anything below the 25 th centile, and have listed any abnormality of the nose or nasal bridge that was noted,

\section{TABLE III}

MAJOR FEATURES OF PATIENTS WITH 21r, 21 DELETIONS AND MONOSOMY OR 22r (no. of cases affected/no. of cases described)

\begin{tabular}{|c|c|c|c|}
\hline Common Features & $\left(\begin{array}{l}21 r^{1} \\
\text { cases })\end{array}\right.$ & $\begin{array}{l}21 \text { deletion }{ }^{2} \text { and monosomy } \\
\text { (5 cases) }\end{array}$ & $\begin{array}{c}22 r^{3} \\
(11 \text { cases })\end{array}$ \\
\hline $\begin{array}{l}\text { Sex } \\
\text { Growth retardation } \\
\text { Mental retardation } \\
\text { Microcephaly } \\
\text { Abnormal ears } \\
\text { Arched palate } \\
\text { Nasal anomalies } \\
\text { Hypertonia } \\
\text { Hypotonia } \\
\text { Micrognathia } \\
\text { Hernia or GU anomalies } \\
\text { Cardiovascular anomalies } \\
\text { Skeletal anomalies } \\
\text { Epicanthal folds } \\
\text { Antimongoloid slant } \\
\text { Syndactyly of toes } \\
\text { Birthweight < } 2.27 \mathrm{~kg} \\
\text { At least one } \mathrm{t}^{\prime \prime} \\
\text { Hypothenar } \\
\text { UL, W, or composites }\end{array}$ & $\begin{array}{l}5 \mathrm{~F} / 3 \mathrm{M} \\
6 / 6 \\
6 / 6 \\
4 / 8 \\
4 / 7 \\
2 / 5 \\
4 / 7 \\
5 / 8^{*} \\
1 / 8 \\
5 / 8 \\
5 / 7 \\
3 / 6^{*} \\
2 / 6^{*} \\
1 /- \\
4 / 8^{*} \\
1 / 7 \\
0 / 7 \\
0 / 6\end{array}$ & $\begin{array}{c}5 \mathrm{~F} / 0 \mathrm{M} \\
5 / 5 \\
5 / 5 \\
4 / 4 \\
4 / 5 \\
3 / 4 \\
4 / 4 \\
2 / 4^{*} \\
1 / 4 \\
5 / 5 \\
0 / 1 \\
3 / 3^{*} \\
3 / 3^{*} \\
1 / \overline{1} \\
4 / 5^{*} \\
3 / 5 \\
0 / 2 \\
0 / 2 \\
\end{array}$ & $\begin{array}{l}7 \mathrm{~F} / 4 \mathrm{M} \\
7 / 10 \\
9 / 9 \\
6 / 10 \\
5 / 9 \\
7 / 8 \\
5 / 7 \\
-1 / 7^{*} \\
1 /- \\
1 /- \\
2 /- \\
10 / 11^{*} \\
1 /- \\
4 / 5^{*} \\
1 / 10 \\
5 / 9^{*} \\
5 / 6^{*} \\
\end{array}$ \\
\hline Occasional Features & $\begin{array}{l}\text { Hypospadias, cryptorchidism, } \\
\text { convulsions, abnormal EEG, } \\
\text { ocular abnormalities }\end{array}$ & $\begin{array}{l}\text { Flexion contractures, hypoplastic } \\
\text { nipples, downy hair on } \\
\text { extremities, achalasia, foot } \\
\text { abnormalities, choanal } \\
\text { stenosis, arthrogryposis }\end{array}$ & $\begin{array}{l}\text { Malocclusion, clinodactyly, } \\
\text { mongoloid slant, hyperkinetic, } \\
\text { synophrys or low hairline, } \\
\text { short } 5 \text { th finger, bifid uvula, } \\
\text { genu recurvatum }\end{array}$ \\
\hline
\end{tabular}

* Indicates main distinguishing feature.

1 Armendares et al, 1971 ; Crandall et al, 1972; Kucerova and Polivkova, 1974; Magenis et al, 1972; Palmer et al, this paper; Shibata et al, 1973; Warren et al, 1973.

2 Gripenberg et al, 1972; Halloran et al, 1974; Mikkelsen and Vesermark, 1974; Richmond et al, 1973 ; Weber et al, 1971.

3 Chauvel et al, 1972; Crandall et al, 1972; Larget-Piet et al, 1974; Lindenbaum et al, 1973; Palmer et al, this paper; Stoll et al, 1973; Turc et al, 1975; Warren et al, 1973; Weleber et al, 1968. 
whereas Turc's table lists only patients with hypertrophy of the nasal bone.

Dermatoglyphic findings were reviewed by Shindler and Warren (1973) who found small differences in the two syndromes. Our data agree with theirs and indicate that despite the absence of truly diagnostic changes there appear to be useful differences. These are summarized in Table IV.

\section{TABLE IV}

DERMATOGLYPHIC FINDINGS IN G DELETIONS

\begin{tabular}{|c|c|c|}
\hline & $21 \mathrm{q}-,-21$, or $21 \mathrm{r}$ & $22 q-,-22$, or $22 r$ \\
\hline Fingerprints & Arches and radial & Whorls \\
\hline $\begin{array}{l}\text { Triradius } \\
\text { Hypothenar pattern } \\
\text { Hallucal pattern } \\
\text { Digital triradii }\end{array}$ & $\begin{array}{l}\text { or } t^{\prime} \\
\text { Absent or } L^{r} \\
\text { Other } \\
\text { More likely to have } \\
\text { absent or mis- } \\
\text { placed } b, c \text {, or d }\end{array}$ & $\begin{array}{l}t^{\prime \prime} \\
W, L^{u} \text { or composites* } \\
W \\
\text { Occasional absent } c\end{array}$ \\
\hline
\end{tabular}

*Not found in!21q-

Perhaps our most interesting finding is the transmission of the ring chromosome from mother to daughter with the simultaneous appearance of an extra X chromosome in the child. Meiotic transmission of rings is known in other organisms including Drosophila (Morgan, 1933), corn (Schwartz, 1953, 1958), and Antirrhinum (Michaelis, 1959). Transmission of a ring chromosome is possible depending on the number and kind of crossover events between the ring and its homologue. Though crossing over between the ring and acrocentric can lead to gametic instability as a result of bridges at first or second meiosis, it is possible to recover a ring chromosome after crossover if, for example, twostrand double crossovers occur. Failure of crossing over would lead to gametes with either or both ring and acrocentric chromosomes. The behaviour of the ring $G$ and its homologue as univalents at meiotic metaphase $I$ has been reported in a ringbearing infertile male (McIlree et al, 1966). Breakdown of spermatogenesis after this division suggests that ring $G$ chromosomes may produce reproductive failure in some males.

To date only one other description of familial ring has been found (Burden et al, 1973). This was a ring 17 chromosome transmitted from a father to one of his four children. Another report (Zdansky et al, 1969) of transmission of a $G$ ring from parent to child is complicated by the presence of normal as well as $\mathrm{G}$ ring and $\mathrm{G}$ monosomic cells in the mother, brother, and maternal uncle of a ring-bearing patient. The presence of the normal cell line in these relatives suggests an inherited instability of $\mathrm{G}$ chromosomes leading to de novo formation of the $G$ ring in the several individuals rather than regular ring transmission.

The simultaneous occurrence of non-disjunction of the $\mathrm{X}$ chromosome and the transmission of the ring can hardly be unrelated phenomena. The inheritance of ring chromosomes is rare as the dearth of reports attests. The frequency of XXX females is 1 in 1000 . That both are present in one patient suggests a connexion between $\mathrm{X}$ non-disjunction and ring transmission. These events might be related by evoking distributive pairing (Grell, 1967). Alternatively one might postulate that the deleted 21 produced some interchromosome interference with segregation, either meiotic or post fertilization, resulting in mis-segregation of the $\mathrm{X}$ chromosome. The possibility of independent $\mathrm{X}$ non-disjunction at meiosis II in either mother or father cannot be ignored. Though genotyping of $\mathrm{X}$-linked markers might have resolved the question it was not possible as this child's true father was not available.

Address all reprint requests and other communications concerning this paper to Dr Catherine G. Palmer, Department of Medical Genetics, Indiana University School of Medicine, 1100 West Michigan Street, Inianapolis, Indiana 46202.

\section{References}

Armandares, S., Buentello, L., and Cantu-Carza, J. M. (1971). Partial monosomy of a $G$ group chromosome $(45, \mathrm{XY}, \mathrm{G}-1$ 46,XY,Gr): report of a new case. Annales de Génétique, 14, 7-12.

Burden, M., Lupascu, E., and Margineanu, L. (1973). A familial case of $17 \mathrm{R}$ ring-shaped chromosome of group $\mathrm{E}$ with transmission from father to son. Revista Medico-Chirurgicală a Societătii de Medici si Naturalisti din Iaşi, 77, 353-357.

Chauvel, P. J., Schindeler, J. D., and Warren, R. J. (1972). G-deletion syndrome II. Humangenetik, 14, 164-166.

Crandall, B. F., Weber, F., Muller, H. M., and Burwel!, J. K. (1972). Identification of $21 \mathrm{r}$ and $22 \mathrm{r}$ chromosomes by quinacrine fluorescence. Clinical Genetics, 3, 264.

Grell, R. F. (1967). Pairing at the chromosome level. Fournal of Cellular Physiology, 70, Suppl. 1, 119-145.

Gripenberg, U., Elfving, J., and Gripenberg, L. (1972). A 45,XX, 21 - child: attempt at a cytological and clinical interpretation of the karyotype. Fournal of Medical Genetics, 9, 110.

Halloran, K. H., Breg, W. R., and Mahoney, M. J. (1974). 21 monosomy in a retarded female infant. Fournal of Medical Genetics, 11, 386.

Hamerton, J. L. (1971). Human Cytogenetics. Academic Press, New York.

Kistenmacher, M. L. and Punnett, H. H. (1970). Comparative behavior of ring chromosomes. American Journal of Human Genetics, 22, 304.

Kucerova, M. and Polivkova, Z. (1974). A case of a girl with a 21 ring chromosome. Human Heredity, 24, 100.

Larget-Piet, L., Rouchy, R., Berthelot, J., Larget-Piet, A., and Collin, G. (1974). Chromosome 22 en anneau (22r). Revue Française de Gynécologie et d'Obstétrique, 69, 195-199.

Lindenbaum, R. H., Bobrow, M., and Barber, L. (1973). Monozygotic twins with ring chromosome 22. Fournal of Medical Genetics, 10, 85.

Lu, K. H. (1968). An information and discriminant analysis of fingerprint patterns pertaining to identification of mongolism and mental retardation. American fournal of Human Genetics, 20, $24-43$. 
McClintock, B. (1938). The production of homozygous deficient tissues with mutant characteritics by means of the aberrant mitotic behaviour of ring-shaped chromosomes. Genetics, 23, 315-376.

McIlree, M. E., Tullock, W. S., and Newson, J. E. (1966). Studies of human meiotic chromosomes from testicular tissue. Lancet, 1, 679.

Magenis, R. E., Armendares, S., Hecht, F., Weleber, R. G., and Overton, $K$. (1972). Identification by fluorescence of two $G$ rings $(46, X Y, 21 r) G$ deletion syndrome $I$ and $(46, X X, 22 r) G$ deletion syndrome II. Annales de Génétique, 15, 265-266.

Michaelis, A. (1959). Uber das verhalten lines ring chromosome in der mitose und meiosis von antirrhinum majus. Chromosoma (Berlin), 10, 144-162.

Migeon, B. R. (1965). Familial variant autosomes: new human cytogenetic markers. Bulletin fohns Hopkins Hospital, 116, 396402.

Mikkelsen, M. and Vestermark, S. (1974). Karyotype 45,XX, - 21/ $46, X X, 21 q-$ in an infant with symptoms of G-deletion syndrome $I$. fournal of Medical Genetics, 11, 389-392.

Morgan, L. V. (1933). A closed X chromosome in Drosophila melanogaster. Genetics, 18, 250-283.

Nakagome, J. Iinuma, K., and Taniguchi, K. (1973). Points of exchange in a human No. 5 ring chromosome. Cytogenetics and Cell Genetics, 12, 35-39.

Neu, R. L., Leao, J. C., and Gardner, L. (1966). Short-arm deletions in G-group chromosomes. Lancet, 2, 390.

Richmond, H. G., MacArthur, P., and Hunter, D. (1973). A 'G' deletion syndrome, anti-mongolism. Acta Paediatrica Scandinarica, 62, 216-220.
Schwartz, D. (1953). Evidence for sister-strand crossing over in maize. Genetics, 38, 251-260.

Schwartz, D. (1958). On the stabilization of a ring chromosome in maize. Genetics, 43, 86-91.

Shibata, K., Waldenmaier, C., and Hirsch, W. (1973). A child with a 21-ring chromosome, $45, \mathrm{XX}, 21-146, \mathrm{XX}, 21 \mathrm{r}$ investigated with the banding technique. Humangentik, 18, 315-319.

Shindler, J. D. and Warren, R. J. (1973). Dermatoglyphics in the G deletion syndromes. Fournal of Mental Deficiency Research, 17, 149-156.

Stoll, C., Rohmer, A., and Sauvage, P. (1973). Chromosome 22 en anneau $\mathbf{r}(22)$. Identification par denaturation themique menagee. Annales de Génétique, 16, 193-198.

Turc, C., Mallard, M., Mabille, J. P., Laurent, C., Veynate, G., and Alison, M. (1975). Chromosome 22 en anneau, $r(22)$ : Une nouvelle observation avec variation de taille de l'anneau et malformations congenitales multiples. Lyon Médical, 233, 317-329.

Warren, R. J. and Rimoin, D. L. (1970). The G deletion syndromes. Fournal of Pediatrics, 77, 658-663.

Warren, R. J., Rimoin, D. L., and Summitt, R. L. (1973). Identification by fluorescent microscopy of the abnormal chromosome associated with the G-deletion syndromes. American Fournal of Human Genetics, 25, 77-81.

Weber, F. M., Sparkes, R. S., and Muller, H. (1971). Double monosomy mosaicism $(45, \mathrm{X} / 45, \mathrm{XX}, 21-)$ in a retarded child with multiple congenital malformations. Cytogenetics, 10, 404-412.

Weleber, R. G., Hecht, F., and Giblett, E. R. (1968). Ring-G chromosome, a new G-deletion syndrome? American fournal of Diseases of Children, 115, 489.

Zdansky, R., Buhler, E. M., Vest, M., Buhler, U. K., and Stalder, G. (1969). Familial G-ring mosaic. Humanyenetik, 7, 275-286. 